\title{
Historical Representation Into the Visual Art Language
}

\author{
Sridewi Asliana ${ }^{1}$, Zulfi Hendri ${ }^{1}$
}

\author{
${ }^{1}$ Master of Arts Education, Yogyakarta State University \\ ${ }^{*}$ Corresponding author. Email: sridewi_asliana@yahoo.co.id
}

\begin{abstract}
Speaking of history, one would usually think of the past, and interpret it as something insignificant. The past has no business of being discussed or remembered. The subject is even often considered extremely tedious, which offers a challenge for the teachers to present the lesson into something exciting and enjoyable. Studying history means searching for the background of an event, whether from the economic, political, or cultural point of view. History is a discipline or study which requires a great deal of critical historical imagination, especially in regard to conventional history. Whereas historians write their research findings in the form of journal articles or books, this paper offers an idea based on the writer's background as a student of art education on how historical imagination can be interpreted in the visual art language. History and art have been viewed as complementary disciplines in the field of education, instead of as primary disciplines such as science, technology, etc. Therefore, this paper attempts to offer a different perspective in viewing history and art as subjects that are equally as important as other sciences.
\end{abstract}

Keywords: representation, history, language, visual, fine arts

\section{INTRODUCTION}

Speaking of history, one would usually think of the past, and interpret it as something insignificant. The past has no business of being discussed or remembered. The subject is even often considered extremely tedious, which offers a challenge for the teachers to present the lesson into something exciting and enjoyable. Studying history means searching for the background of an event, whether from the economic, political, or cultural point of view. History is a discipline or study which requires a great deal of critical historical imagination, especially in regard to conventional history.

In the academic context, history is a field of study or discipline which requires historical imagination in its study. The imagination of a historian is different from that of an artist, as there are boundaries to the historian's imagination based on the historical facts, while artists are subject to limitless imagination [1]. However, it must be noted that art is born from a history, whether the history of the artist's personal life or the surrounding life of the artist. Hence, this paper offers an idea based on the writer's background as a student of art education on how historical imagination can be interpreted in the visual art language. History and art have been viewed as complementary disciplines in the field of education, instead of as primary disciplines such as science, technology, etc. Therefore, this paper attempts to offer a different perspective in viewing history and art as subjects that are equally as important as other sciences.

In the field of education, students have only known history from the events in the materials in the textbook and the explanation from History teachers. It must be admitted that sometimes students are not the most enthusiastic in engaging in the lesson as some students consider historical events as past events and the lesson as extremely tedious. When students are assigned to read historical sources from the textbook, it may be a highly dull routine which makes them drowsy. As a result, students not only fail to understand history fully and only learn on the surface, but also fail to wholly comprehend what triggers those events to occur.

History only tells how an event takes place and has not offered a complete and finished explanation as historians are professional tourists into 
the world of the past [2]. This is why the involvement of art becomes necessary.

There is a great number of artists who represent history into the visual art language. Some make movies or theatrical shows. This paper even considers to present history in a webtoon in order to get accustomed to the youth culture, where visual aspects play an important role in delivering information. Because of this, the visual approach may also help students in imagining an event in the past. In the digital era, the young generation prefer something that is easy and simple, aside from a historical movie in the webtoon format. Thus, in addition to historical films, webtoon may serve as a great alternative to understand history and imagine history better to generate knowledge. There may be an additional touch of creativity in developing movies, shows or webtoon on history which results in differences with the actual event in the past. For instance, to incite emotions in creating a work of art, dramatization is necessary and may take form as sadness, comedy, or thrilling actions.

\section{METHOD}

The problem raised in this study is how to make History learning interesting using the visual art approach. Based on the problem, the paper decided to employ the Research and Development (R\&D) method. Due to the background of the author, which is from the Department of Fine Arts Education, Faculty of Languages and Arts, Yogyakarta State University, this paper provides a perspective on education, namely that science should not belong in boxes. For instance, in the case of arts, it can also be used in the learning method in the History subject. The creativity level of teachers from other disciplines may not be as high as that of the teachers from the arts discipline. Therefore, it is expected that teachers turn a blind eye and only focus on their subject, as they can also develop other subjects, as done in this study, where the History representation method is done in the visual art language, using the Research and Development (R\&D) approach.

In this regard, the study results in a product. In order to produce a certain product, research on needs analysis and to test the product effectiveness is necessary in order to be feasible for the public [3].

In this study, the R\&D method is used as the final result of the research is a new product in the form of an illustrated online book. The decision to select the type of the book was inspired by the online learning phenomenon during the pandemic.

\section{Research Stages}

The stages in a research and development study, can be described as follows [3].

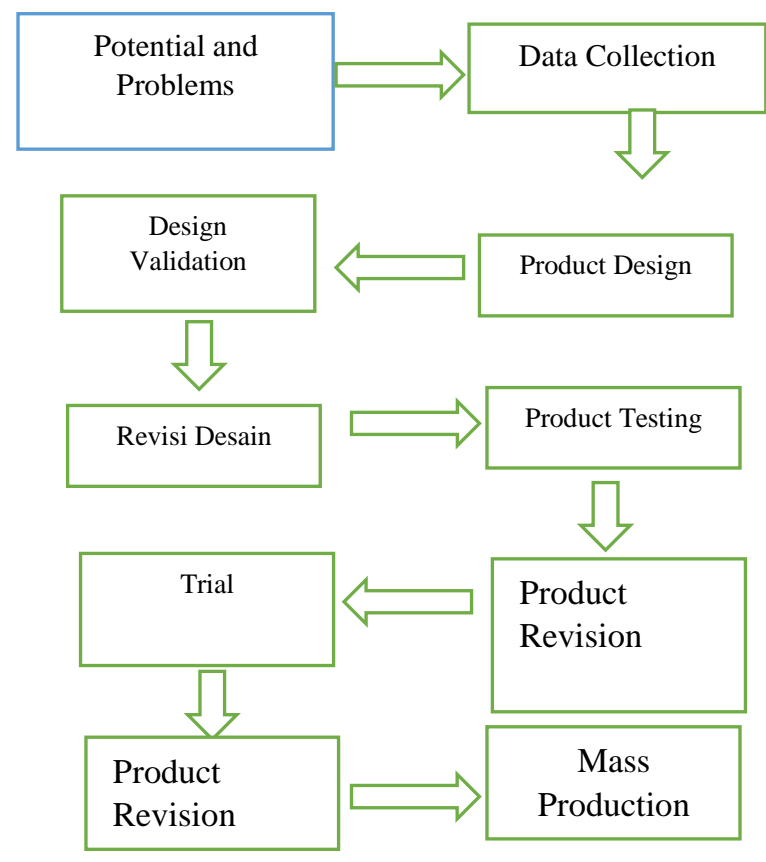

Figure 1 Chart of the R \& D Procedure

This paper applied the ten stages developed by Sugiyono as a research method of this study.

\section{DISCUSSION}

\section{Historical Representation into the Visual Art} Language

\subsection{Representation}

Representation can be defined as a configuration of "forms or assembles" which can depict or represent or symbolize something in a certain way [4]. Representation is the ability to represent, depict or symbolize certain notions in the form of objects or processes.

Historical representation through visual language aims to stimulate and develop the sense of imagination of the students in such a way, that the historical narrative presented can be received as well as challenge their curiosity. History is the panorama of life that is full of colors. In this context, art becomes necessary.

\section{2. $A r t$}

Art is a familiar term for many. It refers to the expression of human feelings which contains elements of aesthetics or beauty and takes form in an actual media which can be received by the human senses. Art is born from events within or outside the artist. Events that occur despite the artist may be current or past events, which were processed into an artwork. In order to produce artwork with a value, there needs to be an amazing, limitless imagination.

It is typical to find art born out of history, whether the history of the artist's life or the history of the artist's surrounding environment. What happens in the 
artist's surrounding refers to an actual discipline, namely the History discipline.

\subsection{History}

In the academic context, History is a discipline or a field of study which requires a critical historical imagination in its study [1]. Meanwhile, Aristotle states that history is a system which identifies events in a chronological order and explains the chronology of an event. He also adds that history is something that happens in the past and can be proven by records.

As an autonomous modern discipline, History needs to be developed based on the pattern of inclination of the field of history itself. Conventional history writing, which composes a mere historical narrative in a descriptive-narrative manner, only explains how an event takes place, without regarding the substantial. In order to obtain a more complete picture of the reality, one needs to approach historical events from various perspectives; this is known as a multidimensional approach, and certainly requires methods from various disciplines, also known as the interdisciplinary method [6].

In the field of education, history is an integral part of the efforts of instilling functional values to instil knowledge. In the development of the History education curriculum, the process needs to address the criteria developed in line with the realistic flexibility characteristics, and oriented toward future interests [5]. The lack of awareness on history is a political weapon that can be used to change certain aspects based on the interest of certain groups. Nevertheless, often History is considered not as a main subject, similar to Art, as the field of education presently remains focusing on the science and technology subjects as the highly needed disciplines in the future, leaving History and Art as merely complementary subjects.

This happens due to several reasons and causeand-effect, one of which is the hyperreality of the History subject as only a transfer of knowledge from the teacher to students through memorization techniques, instead of directing students to think in a comprehensive and critical manner to understand the value in History and Art learning. Art learning at school is also about the transfer of art activities that have been concepted in the form memorization of the techniques. In visual art, for example, students only learn about how to be an artist who produce artworks. This is because in various higher education levels, there is a strong impression on the cognitive aspects which tend to employ memorization. History learning is delivered in isolation from the present time.

Then how do historical representations occur in visual language? Of course, there must be a great indepth study in in understanding what history will be represented. For example, one of the represented history events is the painting entitled The Capture of Pangeran Diponegoro, which shows the illustration on how then Dutch government cornered Pangeran Diponegoro due to his disobedience in condemning the treachery done by the Dutch. The painting was done by Raden Saleh and showed a strong facial expression of Pangeran Diponegoro while he held back his anger. On the contrary, the same event in the Pieneman's version shows Pangeran Diponegoro's defeated and weak expression. According to painting curator Mikke Susasnto, there are a lot of codes in the Raden Saleh's painting, including how the bystanders of the event in the background look the same with a moustache and blangkon (traditional Javanese headwrap). According to Mikke, the face belongs to the painter himself, as a form of support of Raden Salah toward Pangeran Diponegoro.

This representation does not only serve as one of the historical depictions of that era, but can also be a basis for students' imaginations to find out about history in depth. Whereas in the fine arts, the event is manifested in the form of paintings, the representation in webtoon becomes appropriate as the application is practical, accessible, and familiar to today's young generation who consider digital media as a part of their daily lives and needs.

The choice of media appropriately addresses the culture of the younger generation. It is then hoped that there will be no boredom in studying History, compared to learning History using the old method, which forces students to listen to teacher explanations in the class and to read piles of history books. There is a concern that without any novelty in the learning method, students will be even more withdrawn from learning History. Through historical representation in the form of visual language, there can be an alternative choice in providing a History learning method that not only stimulates students' curiosity about history, but also helps build a generation that is much more creative, innovative, as well as critical. It is important that the next generation is one that is aware of history not only as events in the past, but also as events that can provide a perspective of value for the future to help them become a generation that does not only surrender to the circumstances.

Moreover, for the art education students, it is hoped that they will not only be illustrators, but also an idea or orientation that art has an important role in life, and that it can become a necessity to turn something typical, complicated, and boring into something that is interesting and has a higher value. As a result, History and Arts will be seen not only as additional subjects, but a part of the main subjects that are highly crucial in the future, in order to create a new culture to face the world challenges.

In order to realize this idea, it is certainly not an easy task, in regard to hyperreality, as education is still considered as an activity of transferring knowledge from the teacher to the pupils, in addition to the miscommunication between the curriculum developers and those who work in the field, namely teachers or 
lecturers. Hence, the cooperation of both parties is imperative in creating a high-quality generation that is produced by the Indonesian education system in order to compete in the international context.

What kind of solutions are available? What should be done?

The answer is open discussion between the curriculum developers and teachers on the actual condition in the field in order to achieve the objective of education. Additionally, educators must be able to upgrade themselves to be more creative and adapt to the advancement of the age. One of the ways is for the teachers to have the knowledge on the art of teaching on how to manage imagination and immersion on the teaching materials. Imagination and immersion will be improved when teachers have the intellect, abilities, and creative efforts in developing the materials, methods, and media of History learning.

Nevertheless, the condition on the field shows that teachers who possess imagination are less enthusiastic in applying it in the teaching learning process. One of the reasons for this is the workload that they must finish, as well as the fact that Indonesia still emphasizes that all students must be outstanding in all subjects, with the same method, without adjusting to the world of the young generation and highly limited time allocation.

\section{CONCLUSION}

The subject of History, Arts, or other disciplines have the same important values in the scope of education, although in the hyperreality, the public is still trapped in the notion that education is merely about the transfer of knowledge from teacher to pupils, and that learning stops at school, as well as the assumption that science and technology are the main subjects, while history and arts are complementary. These notions are certainly untrue, and may be caused by issues in the curriculum developers and teachers. It is suggested that teachers should be more creative in teaching, as history should not stop at a written and memorization learning context, but also imagination. In this case, the discipline of arts is necessary, as it is commonly recognized that the historians also use historical imagination in tracing back historical facts. Similarly, it is better that the curriculum developers serve as the connector in various aspects, in order to get accustomed with the young generation culture. For instance, this paper proposed that the thick History textbook that is filled with tedious and mind-numbing content be reintroduced in a more interesting format, so that it can be more enjoyable to the youth.

In this case, it is hoped and preferred that professional teachers are not only good at mastering teaching-learning theories and learning materials, but also the skills and the art of teaching or delivering the materials.
Although History is a subject which discusses the past and considered tedious and unimportant by some, the intellectuals will argue that it is like a two-edged sword. If the subject is studied by the wrong person, it can be used as a political weapon to manipulate the future and the facts, and vice versa, when it is on the right hands, an amazing outcome or work may emerge.

Therefore, the presence of art through historical representation in the visual language, whether movies or pictures, will offer a new perspective to stimulate the imagination of the young generation in studying history and seeking new facts that they have yet to find. The hope is that the young generation will be more conscious and further bring Indonesia forward, avoid conflicts and provocation, and improve the youth's ignorance and apathy toward history. It is thus expected that this paper may offer some contribution, although it is acknowledged that there are still many flaws in the study.

\section{REFERENCES}

[1] Sartono Kartodirdjo, "Pembangunan Bangsa, Nasionalisme, Kesadaran dan Kebudayaan Nasional [Nation Development, Nationalism, National Awareness and Culture]." Yogyakarta, Universitas Gadjah Mada, 1990.

[2] Sartono Kartodirdjo, "Pendekatan Ilmu Sosial dalam Metodologi Sejarah [Social Science Approach in Historical Methodology]." Jakarta, PT. Gramedia Pustaka Utama, 1992.

[3] Sugiyono, "Metode Penelitian Kuantitatif, dan $R \& D$ [Quantitative Research Methods, and R\&D]." Bandung, Alfabeta, 2011.

[4] Goldin, G., Representation in Matematical Learning and Problem Solving. Dalam English, Lyn D (Ed) Handbook of International Research in Mathematics Education, 2002. pp. 197-218, Mhwah NJ: Lawrence Erlbaum Associates.

[5] Abbas, H, "Pengembangan IAIN dan STAIN dalam Memasuki Abad 21: Sebuah Pemikiran Konseptual. lekmr seri VIII [Development of IAIN and STAIN in Entering the 21st Century: A Conceptual Thought. lekmr seri VIII]." 1998.

[6] Sartono Kartodirdjo, Pemikiran dan Perkembangan Historiografi Indonesia [Idea and Development of Historiography of Indonesia\}." Jakarta, PT. Gramedia, 1982. 